\title{
APSA Announces New Editorial Team for the American Political Science Review
}

T he American Political Science Association (APSA) has announced a new editorial team for the American Political Science Review (APSR)-the oldest and most prestigious political science journal in the world. After an intensive search for the next editorial team, APSA selected a team from the University of Mannheim (Germany) and the London School of Economics and Political Science (United Kingdom). This appointment marks a historic moment and demonstrates the global orientation of the Review and the Association.

"The APSA is an international organization-in our membership, research topics, students, and public connections-and we are delighted to have an APSR editorial team that will deepen and broaden our networks around the world," said Jennifer Hochschild, APSA president. "Thomas Koenig and his colleagues bring a mix of areas of expertise, philosophical frameworks, and methodologies, and they are already developing plans and innovations. I look forward to seeing the results." The editorial team comprises seven diverse scholars-one lead editor and six associate editors-who are specialized in multiple subfields and methodological perspectives of political science. Each editor is a professor of political science in Europe, and each has an international reputation that has contributed to the discipline.

"We are keenly aware of the enormous responsibility we are taking on," says lead editor Thomas König of University of Mannheim. "We are, however, eager to meet this challenge, and are extremely grateful for the support and confidence expressed in our editorial team by the APSA Council on behalf of the thousands of APSA members."

APSR will benefit enormously from being hosted at two prestigious academic institutions in Europe. Historically housed at a single location, the journal will integrate modern technology to meet and coordinate remotely. This high level of coordination will increase the APSR's global influence and inter-disciplinary recognition.

"The new editorial team follows in this excellent editorial tradition of high quality articles and a rigorous peer-review process," said Steven Rathgeb Smith, APSA executive director. "The new team is also committed to introducing innovations in format and the review process to ensure that that the journal remains responsive to the discipline."

Beginning September 1, 2016, submissions to the APSR have been directed to the new editorial team in Europe. The University of North Texas (UNT) team has begun the transfer of files to the managing office at the University of Mannheim, and we expect the transition to be completed by December 31, 2016. With a backlog of two volumes, the first volume of our editorship will be published in August 2017. The vote by the APSA Council to move the editorship of APSR for the first time outside the United States is an extraordinary historical decision that will help to further globalize APSR and thus to represent our discipline in a broader manner. The team is excited by this challenge and very grateful for the confidence expressed by the APSA council to host the Review in Europe for the next three years. At the same time, they are aware of the concerns about this transition. Their plans for the transition are published on APSA's website (http://www.apsanet.org/ apsreditors).

Following are pictures and short bios from each of the new editors.

\section{LEAD EDITOR}

Thomas König is professor of political science and director of the interdisciplinary center on "The Political Economy of Reforms." He also directs the EITM Europe

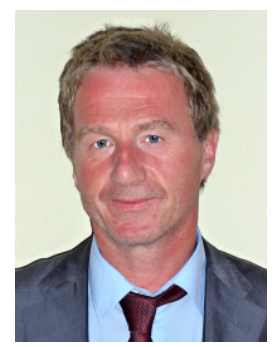
summer institute. His research focuses on international and legislative politics from a comparative perspective. He is a specialist in game theory and quantitative methods. His work has been published in major journals such as Political Analysis, American Journal of Political Science, British Journal of Political Science, Journals of Theoretical Politics, International Organization, Journal of Conflict Resolution, World Politics etc. and major presses such as Cambridge University Press, Princeton University Press, and Springer Press. He is coeditor and board member of many leading journals, including the Journal of
Politics, Political Analysis, Legislative Studies Quarterly, British Journal of Political Science, Political Research and Methods, and Research $\&$ Politics.

\section{ASSOCIATE EDITORS}

Kenneth Benoit is professor of quantitative social research methods, and head of the Department of Methodology at the London School of Economics and Political Sci-

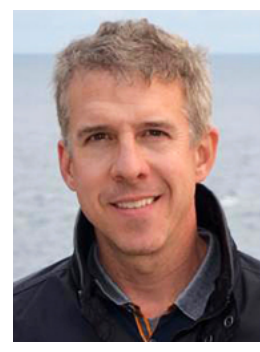
ence. He is also parttime professor in the department of political science at Trinity College Dublin, and has previously held a position at the Central European University (Budapest). He received his $\mathrm{PhD}$ (1998) from Harvard University, department of government. His current research focuses on automated, quantitative methods for processing large amounts of textual data, mainly political texts and social media. Current interests span from the analysis of big data, including social media, and methods of text mining. His substantive research in political science focuses on comparative party competition, the European Parliament, electoral systems, and the effects of campaign spending. His other methodological interests include general statistical methods for the social sciences, especially those relating to measurement. Recent data large-scale measurement projects in which he has been involved include estimating policy positions of political parties through crowd-sourced data, expert surveys, manifesto coding, and text analysis.

Thomas Bräuninger is professor of political economy at the University of Mannheim. His area of research is comparative politics and formal theory with a focus on the effect of political institutions on policy outcomes. He has worked on voting behavior, party politics, electoral systems, legislative

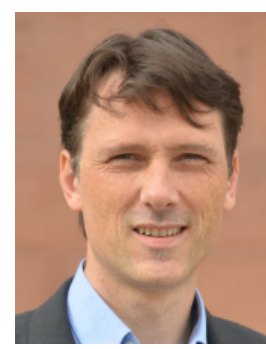


politics, and interest group politics. His teaching interests also include international and comparative political economy, international organizations, and methodology. His work has been published in, among others, the European Journal of Political Research, British Journal of Political Science, Journal of Politics, Journal of Conflict Resolution, Legislative Studies Quarterly, and Political Analysis. He is associate editor of Research $\mathcal{E}$ Politics, he has been a visiting fellow at the University of Pittsburgh and Trinity College Dublin, and he is a member of the Academy of Sciences and Literature.

Sabine Carey is professor of political science at the University of Mannheim. Her research focuses primarily on armed conflict and repression. She is currently work-

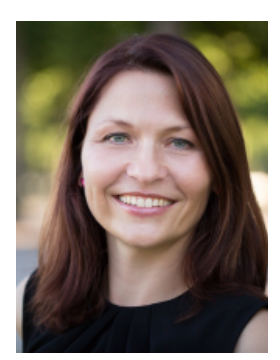
ing on the escalation of conflict supported by an ERC Starting Grant. Previously she was working group leader of the Center for the Study of Civil War and served, among others, as vice president and program cochair of the International Studies Association. Her work has been published with Cambridge University Press and Routledge, and her articles appeared, for example, in International Studies Quarterly, Journal of Peace Research, Journal of Conflict Resolution, Political Research Quarterly, European Union Politics, International Interaction, and Democratization. She has served as associate editor of the Journal of Peace Research and on the editorial boards of the British Journal of Political Science, International Studies Review, and the Journal of Global Security Studies.

Leigh Jenco is associate professor of political theory at the London School of Economics and Political Science. She previously

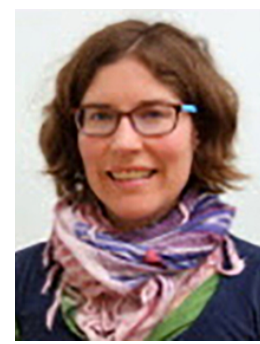

was appointed Postdoctoral Research Fellow at the Political Theory Project, Brown University (2007-2008); and assistant professor of political science at the National University of Singapore (2008-2012). She situates her research and much of her teaching at the intersection of contemporary political theory and modern Chinese thought, emphasizing the theoretical and not simply historical value of Chinese discourses on politics. Her latest book, Changing Referents: Learning Across Space and Time in China and the West, explores the methodological value for comparative political theory of a series of debates by Chinese elites in the nineteenth and twentieth century about what and how to learn from Western culture. She has published her work in such journals as the American Political Science Review, Political Theory, and the Journal of Asian Studies. She has received research and conference grants from the American Council of Learned Societies, the Social Sciences and Humanities Research Council of Canada, the Shibusawa Eiichi Memorial Foundation, and the National University of Singapore.

Benjamin Lauderdale is associate professor in the London School of Economic and Political Science's department of methodology and is affiliated faculty in the department of government. His research is focused on the preferences of and interactions between citizens, legislators and judges in the US, UK and EU, particularly with respect to political representation. He has published extensively on the US Supreme Court and has ongoing research assessing the consistency of decision-making in judicial systems in the US and Europe. He is an expert on methods for the measurement of political preferences from survey, voting, network and text data. His articles have been published in the American Political Science Review, American Journal of Political Science, Political Analysis, Public Opinion Quarterly, Legislative Studies Quarterly, and Electoral Studies.

Ingo Rohlfing is Professor for Qualitative Methods, Political Sciences at the Bremen International Graduate School of Social Sciences (BIGSSS; University of Bremen and

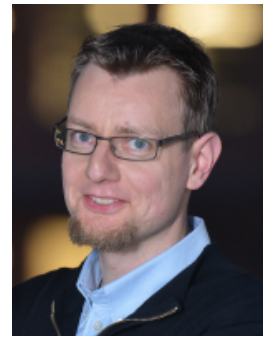
Jacobs University Bremen) and Chair of the BIGSSS Methods Center. His methodological research focuses on case studies and process tracing, Qualitative Comparative Analysis (QCA), and multimethod research combining process tracing with a large-n method. Substantively, he is doing research on party competition in Europe and party organizations. His articles have been published in Comparative Political Studies, Party Politics, Political Research Quarterly, and Sociological Methods \& Research, and he has published the monograph Case Studies and Causal Inference with Palgrave Macmillan. He is coeditor of the Comparative Politics Series at Nomos and member of the advisory board of the network on Comparative Methods for Systematic Cross-Case Analysis (COMPASSS). The European Research Council (ERC) awarded him an ERC Starting Grant for his 5-year project Enhanced Qualitative and Multimethod Research. 